ANUVA Volume 2 (4): 399-412, 2018

Copyright (C2018, ISSN: 2598-3040 online

Available Online at: http://ejournal.undip.ac.id/index.php/anuva

\title{
Identifikasi Bangunan Cagar Budaya Di J awa Tengah (Studi Eks Rumah Dinas Residen)
}

\author{
Alamsyah $\left.{ }^{1 *}\right)$ \\ ${ }^{1}$ Program Studi Sejarah, Fakultas Ilmu Budaya, Universitas Diponegoro, \\ Jl. Prof. Soedarto, SH, Kampus Undip Tembalang, Semarang, Indonesia \\ ${ }^{*}$ Korespondensi: alam_mahir@yahoo.com
}

\begin{abstract}
The former resident's official residence houses in several areas in Central Java are buildings that can be categorized as cultural heritage buildings. This building is a guided structure made of man-made objects to meet the needs of walled and roofed space. This building is a historical heritage that is more than 50 years old, has a style period of more than 50 years, and has significance for the history and science. The former resident's official residence is a relic of the Dutch East Indies government that was used as the center of government and residence of the residents and their families. The existence of a resident's official residence is a form of the presence of the binnenlandsch bestuur's bureaucracy (colonial bureaucracy), resident, whose structure was under the governor general and above the assistant resident. As a cultural heritage building, the existence of this building must be preserved, developed and utilized for the welfare of the community.
\end{abstract}

Keyword: Buildings; cultural heritage; official recidence; residents.

\begin{abstract}
Abstrak
Bangunan eks rumah dinas residen yang ada di beberapa daerah di Jawa Tengah merupakan bangunan yang dapat dikategorikan sebagai bangunan cagar budaya. Bangunan ini merupakan susunan binaan yang terbuat dari benda buatan manusia untuk memenuhi kebutuhan ruang berdinding dan beratap. Bangunan ini merupakan peninggalan sejarah yang berusia lebih dari 50 tahun, mempunyai masa gaya lebih dari 50 tahun, dan mempunyai arti penting bagi sejarah dan ilmu pengetahuan. eks rumah dinas residen merupakan bangunan peninggalan pemerintah Hindia Belanda yang digunakan sebagai pusat pemerintahan dan kediaman residen beserta keluarganya. Adanya rumah dinas residen merupakan bentuk hadirnya birokrasi binnenlandsch bestuur (birokrasi kolonial), residen, yang strukturnya berada di bawah gubernur jenderal dan di atas asisten residen. Sebagai bangunan cagar budaya, maka keberadaan bangunan ini harus dilestarikan, dikembangkan, dan dimanfaatkan untuk kesejahteraan masyarakat.
\end{abstract}

Kata kunci: Bangunan; cagar budaya; rumah dinas; residen.

\section{Pendahuluan}

Jawa Tengah kaya peninggalan sejarah yang merupakan warisan budaya. Warisan budaya ini dapat berupa hasil budaya fisik (tangible) dan nilai budaya (intangible) dari masa lalu (Arafah, tanpa tahun). Cagar budaya sebagai warisan budaya fisik (tangible) merupakan kekayaan budaya bangsa sebagai wujud pemikiran dan perilaku kehidupan manusia yang penting artinya bagi pemahaman dan pengembangan kebudayaan dalam kehidupan bermasyarakat, berbangsa, dan bernegara. Sebagai warisan budaya, cagar Budaya perlu dilestarikan keberadaannya karena memiliki nilai penting bagi sejarah, ilmu pengetahuan, pendidikan, agama, dan/atau kebudayaan. Cagar Budaya dapat berupa Benda Cagar Budaya, Bangunan Cagar Budaya, Struktur Cagar Budaya, Situs Cagar Budaya, dan Kawasan Cagar Budaya. Bangunan 
Cagar Budaya merupakan salah satu warisan budaya masa lampau (Undang-Undang Republik Indonesia Nomor 11 Tahun 2010; Peraturan Daerah Provinsi Jawa Tengah Nomor 10 Tahun 2013)

Bangunan cagar budaya peringkat provinsi di Jawa Tengah diantaranya adalah bangunan eks rumah dinas residen. Bangunan eks rumah dinas residen ini tersebar di beberapa daerah diantaranya rumah dinas residen Pati, rumah dinas residen Kedu, rumah dinas residen Pekalongan, dan rumah dinas residen Banyumas (TACB, 2017). Dalam struktur birokrasi kolonial, residen merupakan perpanjangan tangan pemerintah kolonial. Residen membawahi sejumlah asisten residen dan beberapa bupati. Tugas residen berkaitan dengan masyarakat sipil, militer, pengadilan, pajak, dan keuangan (Day, 1904: 194). Tugas residen juga berkaitan dengan fungsi sosial, politik, bertanggung jawab penuh atas wilayah dan penduduknya, serta mewujudkan ketertiban dan keamanan (Wijaya, 2017: 59; Setiyanto, 2015: 123).

Untuk memperlancar tugas residen, pemerintah kolonial Hindai Belanda membangun rumah dinas residen guna menunjang kegiatan pemerintahan. Eks rumah dinas residen di Jawa Tengah masih berdiri dan menjadi warisan budaya berupa bangunan cagar budaya. Atas dasar itu maka studi tentang Identifikasi Bangunan eks Rumah Dinas Residen sebagai bangunan cagar budaya penting dilakukan untuk memotret kelayakan bangunan ini sebagai bangunan cagar budaya peringkat Provinsi.

\section{Metode Penelitian}

Metode penelitian yang dilakukan dalam menemukan dan mengumpulkan sumber atau informasi (heuristik) lebih mendasarkan pada sumber sekunder berupa form hasil kajian Tim Ahli Cagar Budaya (TACB) Provinsi Jawa Tengah tentang Bangunan Cagar Budaya Eks rumah dinas residen, dan pustaka berupa buku, hasil penelitian, dan jurnal yang relevan. (Garraghan, 1947: 34; Gottschalk, 1975: 32; Herlina, 2008: 17-24; Beni Ahmad Saebani, tt: 162-163).). Sumber sekunder tersebut diperoleh dari perpustakaan maupun dari browsing di internet. Sumber yang tersedia kemudian dilakukan kritik dan interpretasi. Tahapan selanjutnya adalah dilakukan klasifikasi, dihubung-hubungkan atau diakumulasikan antara data satu dengan yang lainnya, sebagai suatu bentuk interpretasi dan sintesa dalam rangka mererekonstruksi menjadi sebuah artikel.

\section{Hasil dan Diskusi}

\subsection{Sejarah Keresidenan di Jawa Tengah}

Dalam konteks historis, Semarang telah menjadi ibukota wilayah pantai utara-timur Jawa (J ava's Northeast Coasts) pada tahun 1708 yang dipimpin oleh seorang gubernur (Suroyo, dkk, 2003: 54; Suryo, 1989: 2-7). Pada masa Raffles, Jawa dibagi dalam 17 wilayah keresidenan. Setiap wilayah dipimpin oleh residen Eropa dan dibagi dalam beberapa kabupaten. Setiap residen dibantu oleh seorang asisten residen. Pada masa Hindia Belanda, pada tahun 1855 Jawa dibagi dalam daerah-daerah administratif yang disebut gewest atau residensi yang dipimpin oleh seorang residen (Sutherland, 1988: 9; Suroyo, dkk., 2003: 56; Suroyo, 2003: 56-58). 
Pada tahun 1900, di wilayah Jawa Tengah terdapat lima gewesten (keresidenan) yaitu: Semarang, Rembang, Kedu, Banyumas, dan Pekalongan. Secara yuridis, Jawa Tengah sebagai sebuah provinsi berdiri berdasarkan keputusan pemerintah 20 Mei 1933 (Staadsblad 1933 No. 251) dengan ibu kota Semarang (Suroyo, dkk, 2003: 69). Pada tahun tersebut, Provinsi Jawa Tengah mencakup lima residensi, yaitu Residensi Pekalongan, Residensi Semarang, Residensi Jepara-Rembang, Residensi Banyumas, dan Residensi Kedu.

Pada masa Jepang 1942, jabatan gubernur Jawa Tengah yang berkedudukan di Semarang dipegang oleh orang Jepang yaitu Letnan Kolonel Taga dengan didampingi oleh Rd. Muhammads Chalil sebagai Wakil Gubernur Jawa Tengah dan Salaman sebagai residen (Suroyo, dkk., 2003: 74-75). Struktur birokrasi Jepang diantaranya adalah keresidenan (shu), kawedanan (gun), dan kecamatan (son) yang berada di bawah Departemen Urusan Dalam Negeri (Naimubu) di Jakarta dan bertanggung jawab kepada Komando Tentara Keenambelas (Sutherland, 1979: 258; Suroyo, dkk., 2003: 80). Pada saat itu, pemerintah daerah yang tertinggi adalah shu karena bagian pemerintahan yang paling tinggi di daerah (Suroyo, dkk.,2003: 81).

Pasca Kemerdekaan, status provinsi Jawa Tengah dikuatkan oleh PPKI pada tahun 1945, berdasarkan ketetapan PPKI tanggal 19 Agustus 1945 No. 1 yang dimuat dalam Undang-Undang 1945 Nomor 1. Pada periode ini, wilayah administrasi Provinsi Jawa Tengah meliputi Keresidenan Kedu, Banyumas, Pekalongan, Semarang, dan Rembang. Bertolak dari sejarah birokrasi keresidenan di atas, maka posisi residen sangat penting pada masa Hindia Belanda, Jepang, awal kemerdekaan, bahkan pada masa orde lama, dan orde baru. Melihat peran penting tersebut, maka keberadaan rumah dinas residen sebagai tempat tinggal dan tempat dinas residen sangat signifikan dalam menggerakkan dinamika administrasi pemerintahan.

\subsection{Bangunan Cagar Budaya}

Cagar budaya merupakan kekayaan budaya bangsa sebagai wujud pemikiran dan perilaku kehidupan manusia yang penting artinya bagi pemahaman dan pengembangan sejarah, ilmu pengetahuan, dan kebudayaan dalam kehidupan bermasyarakat, berbangsa, dan bernegara. Oleh sebab itu cagar budaya perlu dilestarikan dan dikelola secara tepat melalui upaya pelindungan, pengembangan, dan pemanfaatan dalam rangka memajukan kebudayaan nasional untuk sebesar-besarnya kemakmuran rakyat. Dalam hal ini, negara bertanggung jawab dalam pengaturan pelindungan, pengembangan, dan pemanfaatan cagar budaya (Undang-Undang No.11 Tahun 2010). Bangunan Cagar Budaya adalah susunan binaan yang terbuat dari benda alam atau benda buatan manusia untuk memenuhi kebutuhan ruang berdinding dan/atau tidak berdinding, dan beratap. Bangunan cagar budaya perlu dikelola oleh pemerintah dan pemerintah daerah dengan meningkatkan peran serta masyarakat untuk melindungi, mengembangkan, dan memanfaatkan cagar budaya. Untuk melestarian cagar budaya, diperlukan keseimbangan aspek ideologis, akademis, ekologis, dan ekonomis guna meningkatkan kesejahteraan rakyat. 
Sebuah bangunan bersejarah perlu ditetapkan sebagai bangunan Cagar Budaya berdasarkan peringkatnya. Tahapan pengajuan bangunan warisan budaya sebagai bangunan cagar budaya diantaranya adalah melalui pendaftaran, pengkajian, penetapan, dan pemeringkatan. Pendaftaran bangunan cagar budaya dapat dilakukan oleh individu atau pemerintah. Hasil pendaftaran ini dilengkapi dengan deskripsi dan dokumentasinya. Hasil pendaftaran diserahkan kepada Tim Ahli Cagar Budaya (TACB) untuk dikaji kelayakannya sebagai Cagar Budaya atau bukan Cagar Budaya. Pengkajian bertujuan melakukan identifikasi dan klasifikasi terhadap bangunan yang diusulkan untuk ditetapkan sebagai Cagar Budaya. Hasil pengkajian dikeluarkan dalam bentuk rekomendasi oleh TACB. Dalam melakukan kajian, TACB dapat dibantu oleh Satuan Kerja Perangkat Daerah atau Unit Kerja yang membidangi Cagar Budaya. Selama proses pengkajian, bangunan hasil penemuan atau yang didaftarkan, dilindungi dan diperlakukan sebagai Cagar Budaya. Penetapan status Cagar Budaya dikeluarkan oleh Bupati/Walikota paling lama 30 (tiga puluh) hari kalender setelah rekomendasi diterima dari TACB yang didaftarkan layak sebagai Cagar Budaya. Penetapan tersebut dilakukan oleh pemerintah kabupaten/kota berdasarkan rekomendasi TACB. (Peraturan Daerah Provinsi Jawa Tengah Nomor 10 Tahun 2013). Bila sudah ditetapkan sebagai cagar budaya, bangunan tersebut perlu dilestarikan karena merupakan warisan budaya bangsa dan warisan umat manusia (Undang-Undang No.11 Tahun 2010).

TACB mempunyai tugas menyusun dan menetapkan mekanisme tugas, melakukan kajian atas berkas yang diusulkan oleh tim pendaftaran cagar budaya, memberikan rekomendasi penetapan, pemeringkatan, dan penghapusan (Keputusan Dirjen Kebudayaan Nomor 100/ E.E 2/ KP/ 2018)

\subsection{Identifikasi Bangunan Cagar Budaya Eks Kantor Residen di Jawa Tengah}

\section{a. Eks Rumah Dinas Residen Banyumas}

Eks Kantor Residen Banyumas terletak di Jl. Pramuka No.1 Banyumas. Bangunan ini diprakarsai oleh Pemerintah Kolonial Hindia Belanda. Bangunan ini dibangun sekitar 1831 ketika pelatikan pertama Residen Banyumas pertama, de Sturler. Keresidenan Banyumas sebelumnya adalah daerah Monconegoro Kulon dari kerajaan Mataram Islam. Setelah perang Diponegoro berakhir daerah Monconegoro Kulon dan Wetan diambil alih oleh Belanda sebagai imbalan atas pemadaman perang Diponegoro, karena Belanda menganggap bahwa perang Diponegoro adalah pemberontakan terhadap kerajaan Mataram dan bukan terhadap Belanda (Surat Keterangan Cagar Budaya TACB Jawa Tengah Banyumas Nomor. 432/5863, 2017: 3) 


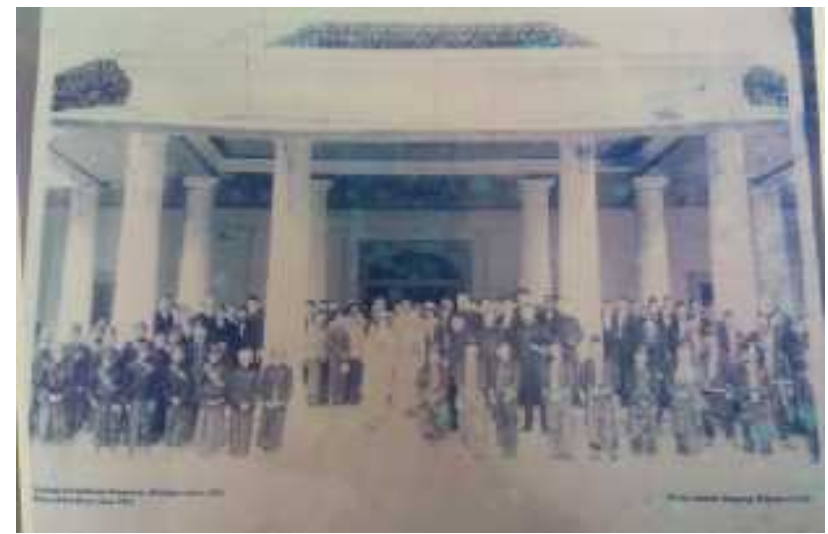

Gambar 1. Kantor eks Keresidenan Banyumas Dibangun Tahun 1843, dan diabadikan Tahun 1992 Sumber : Koleksi Foto Bakorwil III yang Didokumentasi ulang TACB Jateng, 4 Desember 2015

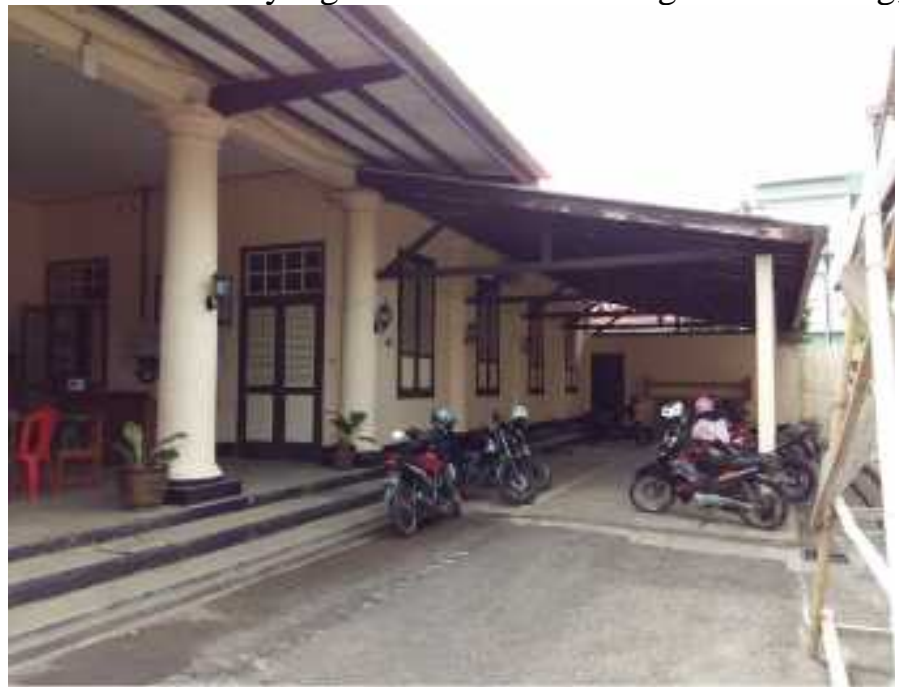

Gambar 2: Bangunan Eks Rumah Dinas Residen Banyumas dari sisi Bagian Barat Sumber: Dokumentasi TACB Jateng, Desember 2015

Pada tahun 1830 telah dirintis pendirian Keresidenan Banyumas oleh Gubernur Jenderal Van den Bosch. Pada 1 Nopember 1830 ditetapkan residen Banyumas yang pertama yaitu De Sturler dengan wilayah Kebumen, Banjarnegara, Panjer, Ayah, Purbalingga, Banyumas, Kroya, Adireja, Patikraja, Purwokerto, Ajibarang, Karangpucung, Sidareja, Majenang, dan Dayeuh Luhur. Selanjutnya 18 Desember 1830 berdasarkan beslit Gubernur Jenderal J.G. van den Bosch, di Banyumas dibentuk 4 Kabupaten (regentschap) yaitu Banyumas, Ajibarang, Dayeuh Luhur, dan Banjarnegara. Pada tanggal 22 Agustus 1831 Residen De Sturler membentuk afdeling atau wilayah administrasi di keempat kabupaten tersebut dengan administratornya adalah Asisten Residen yang dijabat oleh seorang Belanda. Pembentukan afdeling ini bertujuan untuk lebih menertibkan administrasi perkebunan, mengingat pada waktu itu telah diterapkan pengelolaan tanaman ekspor dalam bentuk perkebunan yang terkenal dengan tanam paksa. Penduduk diharuskan menanam tanaman tertentu atas perintah bupati, setelah terkumpul, produk tersebut selanjutnya di ekspor oleh Belanda. Dalam kegiatan di tingkat kabupaten ini diawasi dan dikelola oleh Asisten Residen (Surat Keterangan Cagar Budaya TACB Provinsi Jawa Tengah Banyumas Nomor. 432/5863, 2017: 3) 
Sebagai sebuah Keresidenan, keberadaan rumah dinas residen menjadi penting untuk menggerakkan pemerintahan dan perekonomian dari dan menuju hinterland di daerah lembah Sungai Serayu sepanjang abad ke-19. Hasil-hasil perkebunan yang merupakan komoditas ekspor yang dihasilkan di wilayah Karesidenan Banyumas, terutama kopi, dikirim melalui kota, kemudian dibawa dengan melalui Sungai Serayu menuju Pelabuhan Cilacap untuk dikapalkan (Margana, 2010: 19). Pada periode ini masyarakat Banyumas diperkenalkan dengan sistem pengelolaan tanaman ekspor perkebunan. Tanaman yang dikenal di Keresidenan Banyumas antara lain tembakau, kopi, kapas, dan gula tebu. Pada tahun 1839, di daerah ini telah dibangun pabrik gula di Kalibagor, Klampok, dan Bojong. Jalur-jalur transportasi di daerah Banyumas yang sebelumnya sempit diperlebar dan diperkeras. Selain itu dibuat jalur baru seperti Banyumas-Buntu hingga Gombong serta Banyumas-pelabuhan Cilacap (Surat Keterangan Cagar Budaya Banyumas Nomor. 432/5863, 2016: 4)

Transportasi modern bermesin seperti kereta api dikembangkan oleh SDS (Serajoe Dal Stoomtram Maatchapij) di hampir seluruh wilayah karesidenan Banyumas pada 1896. Transportasi jalan maupun kereta api telah membuat karesidenan Banyumas menjadi terbuka. (Surat Keterangan Cagar Budaya Banyumas Nomor. 432/5863: 2017: 4)

Eks Rumah Dinas Residen Banyumas ini memiliki gaya arsitektur Empire Style. Ciri-ciri umumnya adalah pada atap berbentuk Limasan dikelillingi oleh entablature dan pilar-pilar gaya Doria atau Ionia mengelilingi gedung atau hanya bagian fasade dan teras belakang. Tata ruang pada bangunan utama biasanya memiliki bagian teras depan dan belakang yang terbuka, ruang dalam terdiri atas ruang tamu yang besar, di belakangnya adalah kamar-kamar, yang dipisahkan secara simetris oleh lorong. Lorong ini menghubungkan antara ruang tamu dengan teras belakang melalui sebuah pintu. Arsitektur Empire Style ditemukan pada deretan pilar depan bangunan paviliun sisi barat dan paviliun sisi timur. Atap Limasan pada bangunan paviliun sisi barat dengan penambahan dinding entablature ditopang pilarpilar dengan gaya Doria. Antara paviliun sisi barat dan timur bagian depan dihubungkan dengan dinding tanpa atap ke bangunan utama. Pada fasade Bangunan utama masih terdapat sisa-sisa pilar Empire Style ((Surat Keterangan Cagar Budaya Banyumas Nomor. 432/5863: 2017: 4)

\section{b. Eks Rumah Dinas Residen Kedu}

Eks Rumah Dinas Residen Kedu terletak di Jl. Diponegoro No.1 Magelang. Bangunan ini diprakarsai oleh Pemerintah Kolonial Hindia Belanda, dirancang oleh J.C Schulze, dan dibangun oleh masyarakat pribumi Magelang. Bangunan ini dibangun pada tahun 1813-1921. Eks rumah dinas Residen Kedu dirancang dengan gaya arsitektur indis, yaitu perpaduan antara gaya empire style dan gaya lokal. Gaya lokal dapat dilihat dari atap bangunan yang berbentuk limasan. Selain itu bangunan ini juga bergaya tropis dengan ventilasi banyak dan besar. Bangunan ini juga memiliki teras pada bagian depan dan belakang, dengan halaman depab dan belakang yang sangat luas (Surat Keterangan Cagar Budaya Kedu Nomor. 432/5861: 2017: 3)

Copyright @2018, ISSN: 2598-3040 online 
Pada tahun 1869, Magelang merupakan wilayah administratif kabupaten di bawah Keresidenan Kedu. Kabupaten Magelang terdiri atas beberapa distrik yaitu Minoreh, Bandongan, Magelang, Ngasinan, Ballak, Probolinggo, dan Remaneh (Veth, 1869). Pada tahun 1869, penduduk Magelang berjumlah 241.575 jiwa. Ibu kota Kabupaten Magelang berlokasi di Magelang. Daerah ini sangat subur dan dilalui oleh sungai Bengawan Solo serta dikelilingi oleh perkebunan tembakau (Surat Keterangan Cagar Budaya Kedu Nomor. 432/5861: 2017: 3)

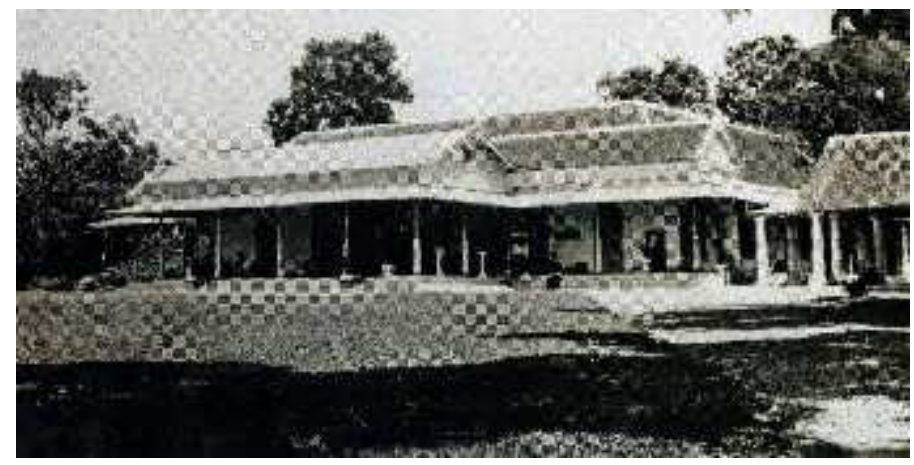

Gambar 3: Bangunan Depan menghadap ke barat

Sumber : Museum Tropen Amsterdam, dikunjungi Tahun 2016, Koleksi TACB Jawa Tengah 2016

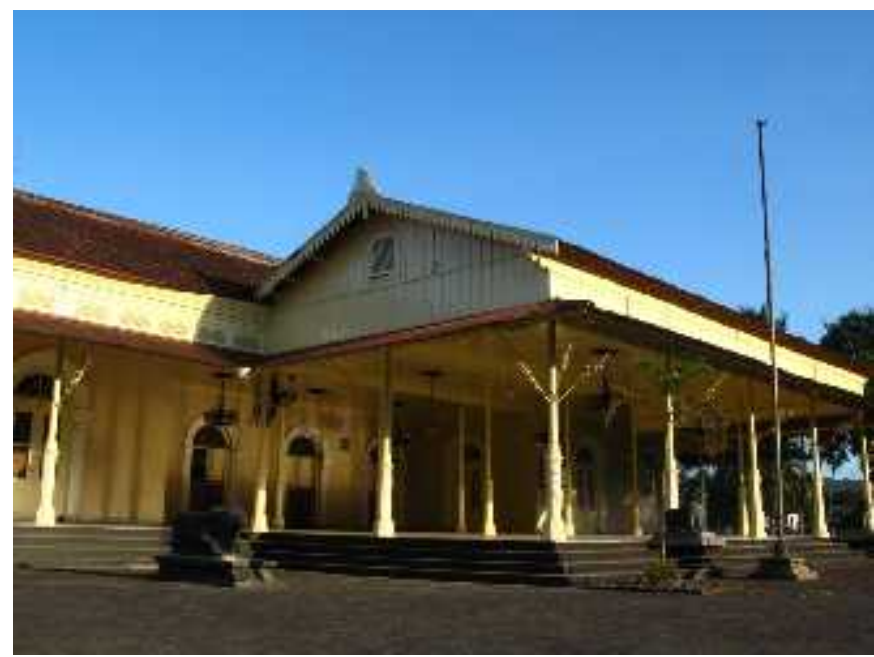

Gambar 4: Bangunan Eks Rumah Dinas Residen, Tampak Veranda Depan, Menghadap ke Arah Barat Sumber: Koleksi TACB Jawa Tengah 2016

Ibu Kota Keresidenan Kedu berlokasi di Kabupaten Magelang, terletak di daerah perbukitan yang merupakan muara dari sungai Progo. Magelang menjadi tempat tinggal residen Kedu, tempat tinggal bupati Magelang, sekretaris residen, kepala pergudangan, dan 2 orang bendahara pemerintah, juragan garam, 4 orang kontrolir pendapatan daerah dan perkebunan, 2 orang pengawas perkebunan teh, seorang pengawas perkebunan nila, seorang tenaga kesehatan, dan pegawai kesehatan yang melayani urusan kesehatan masyarakat. Di Magelang juga ada pengadilan negeri (landraad), seorang agen kamar dagang, sebuah kantor pajak dan pertanahan, dan kantor urusan agama pemerintah. Di Magelang juga terdapat sekolah rendah dan sekolah untuk orang pribumi yang didirikan pada bulan Juni tahun 1851. (Surat Keterangan Cagar Budaya Kedu Nomor. 432/5861, 2017: 3)

Copyright @2018, ISSN: 2598-3040 online 
Eks Bangunan rumah dinas Residen Kedu merupakan bangunan bergaya empire style yang dipadu dengan fungsi-fungsi yang disesuaikan dengan iklim tropis. Hal in terlihat dari adanya bangunan veranda (beranda) di bagian depan dan belakang, ada pintu rangkap yang satu pintu krepyak (jalusi), yang satu pintu yang menggantung yang dapat diayun yang tinggi dan lebar. Bangunan ini dilengkapi taman di bagian belakang dan pohon-pohon tropis di sampingnya. Kanopi pada jendela untuk menahan percikan air hujan (Surat Keterangan Cagar Budaya Kedu Nomor. 432/5861, 2017: 5).

\section{c. Eks Rumah Dinas Residen Pati}

Eks Rumah Dinas Residen Pati terletak di Jl. Panglima Sudirman No.3 Pati. Pembagunan eks rumah dinas ini diprakarsai oleh Pemerintah Kolonial Hindia Belanda. Bangunan ini diperkirakan dibangun pada 1810, dimana pada tahun tersebut ibu kota Keresidenan Jepara yang semula berada di Jepara dipindahkan ke Pati. Arsitekturnya bergaya empire style dengan mendapat tambahan yang disesuaikan dengan kondisi daerah tropis. Arsitektur empire style pada bangunan rumah dinas residen Pati ditemukan pada deretan pilar bagian depan bangunan. Atap limasan pada bangunan ditopang pilar-pilar dengan gaya Doria.

Keresidenan Pati baru dibentuk pada tahun 1835-an. Sejak masa VOC hingga 1900, Pati merupakan bagian dari Keresidenan Jepara. Keresidenan Jepara meliputi Kabupaten Jepara, Pati, Kudus, dan Juana. Pada tahun 1810, ibu kota dan kantor Keresidenan Jepara yang semula di Jepara, dipindah ke Pati (Van der Lith, 1896: 98). Perubahan administrasi ibu kota dan kedudukan residen dari Jepara ke Pati disebabkan Jepara mengalami penurunan kemakmuran. Sejak tahun 1810, wilayah Jepara tidak seramai tahun sebelumnya karena wilayah ini terletak di ujung yang jauh dan menjorok serta pelabuhannya mengalami kemuduran (Veth, 1882: 765; der Aa, 1857: 274). Pati menjadi ramai karena dilewati pembangunan jalan raya Daendels yang menghubungkan kota-kota di wilayah pantai utara Jawa. Kondisi inilah yang melatarbelakangi pusat Pemerintahan Keresidenan Jepara dipindahkan ke Pati oleh Daendels pada tahun 1810. Pada tahun berikutnya tempat tinggal residen yang semula di Jepara pindah ke Pati (Van der Lith, 1896: 99; Veth. 1882: 765). Pada abad ke-19, wilayah Pati mempunyai 519 desa. Pada tahun 1830, jumlah distrik di Pati 6 distrik meliputi Pati, Tenggeles, Selowesi, Cengkalsewu, Angkatan, Glonggong, dan Bogorame (Algemeen Verslag Residentie Japara en Joana 1830: 1 ; Van der Aa, 1857: 262; Surat Keterangan Cagar Budaya Pati Nomor. 432/5865: 2017: 3).

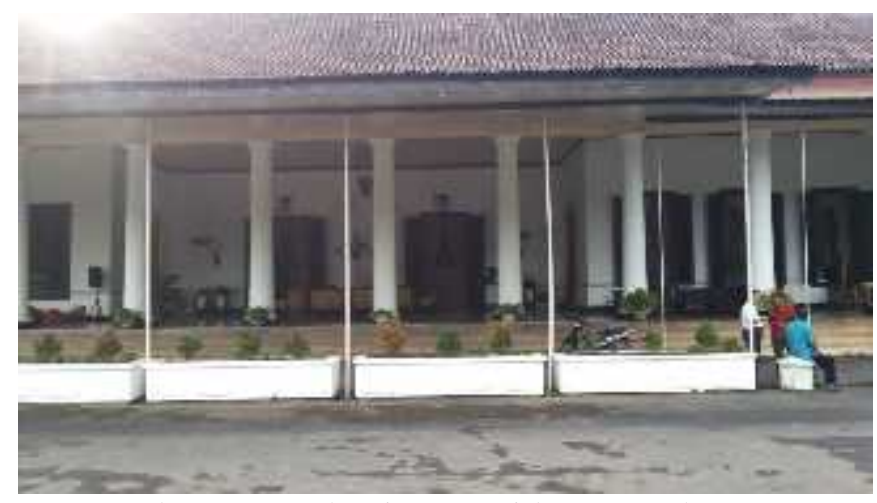

Gambar : Rumah Dinas Residen tampak Depan

Copyright @2018, ISSN: 2598-3040 online 
Sumber: Dokumentasi TACB Jateng, 2015.

Pejabat yang bertugas di Pati adalah residen dan asisten residen. Residen membawahi sistem pemerintahan di seluruh wilayah Keresidenan ini. Dia membawahi asisten residen dan bupati. Dalam menjalankan pemerintahannya, residen dibantu oleh asisten residen dan sekretaris. Tugas sekretaris residen adalah mengelola kas negara, memegang fungsi sebagai notaris dan juru lelang. Residen juga dibantu oleh empat orang kontrolir (Veth, 1869: 548). Pembagian wilayah di keresidenan ini mengalami perubahan seiring dengan terbitnya Lembaran Negara 1874 nomor 73. Perubahan yang terjadi adalah wilayah kabupaten terbagi dalam distrik dan onderdistrik (Algemeen Verslag Der Residentie Japara Over Het Jaar 1874 Bundel No. 7.II.; Surat Keterangan Cagar Budaya Pati Nomor. 432/5865: 2017: 3).

Bangunan ini secara keseluruhan masih utuh dan terawat. Bangunan utama bergaya empire style yang dipadu dengan fungsi-fungsi yang disesuaikan dengan iklim tropis, contohnya adanya bangunan veranda (beranda) di bagian depan dan belakang, ada pintu rangkap yang satu pintu krepyak (jalusi), yang satu pintu yang menggantung yang dapat diayun yang tinggi dan lebar, taman yang luas dengan pohonpohon tropis, adanya kanopi pada jendela untuk menahan hujan. Di bagian beranda depan terdapat kamar di bagian kiri dan kanan yang pada tahun 1965-1967 digunakan untuk tempat penahanan dan penyiksaan orang-orang PKI (Surat Keterangan Cagar Budaya Pati Nomor. 432/5865: 2017: 4-7).

\section{d. Eks Rumah Dinas Residen Pekalongan}

Eks rumah dinas residen Pekalongan terletak di Jl. Pemuda No.1, Kota Pekalongan. Bangunan ini dibangun oleh Pemerintah Kolonial Hindia Belanda pada 1850. Arsitektur bangunan ini bergaya empire style. Gaya ini terlihat dari adanya barisan pilar atau kolom yang menjulang ke atas. Selain itu terdapat gevel dan mahkota di atas serambi depan.

Keberadaan bangunan ini tidak terlepas dengan adanya Perjanjian Jepara tahun 1676 antara Mataram dengan VOC, dimana Amangkurat II menyerahkan pesisir Utara Jawa ke VOC sebagai konsesi atas penumpasan Trunojoyo. Hal ini diperkuat dengan adanya perjanjian antara VOC dengan Paku Buwono II pada 18 Mei 1746 yang isinya Pulau Madura dan seluruh pesisir Utara Jawa menjadi milik VOC dan wilayah itu bukan lagi menjadi bagian dari wilayah Mataram. Kekuasaan Belanda atas pesisir utara Jawa diperkuat dengan perjanjian Giyanti yang membelah Mataram di bawah dua raja, Sunan Paku Buwono di Keraton Surakarta dan Sultan Hamengku Buwono di Keraton Yogyakarta (Surat Keterangan Cagar Budaya Pekalongan Nomor. 432/5860: 2017: 2-3). 


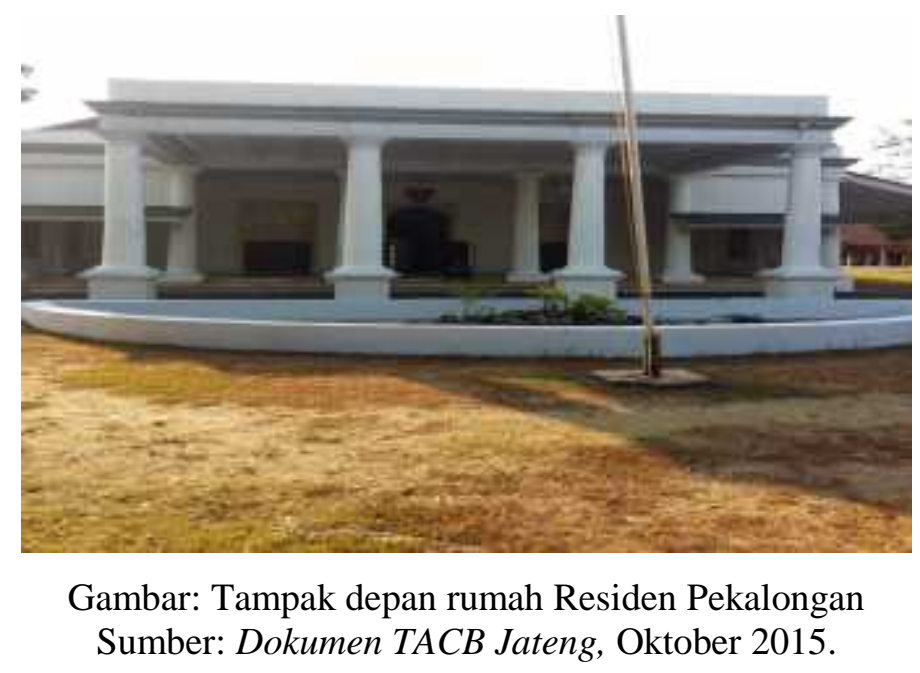

Pada tahun 1836, Pekalongan dipimpin oleh residen Praetorius yang menjabat sampai tahun 1841. Penggantinya adalah residen F.H. Doornik. Keresidenan Pekalongan merupakan salah satu wilayah dimana Cultuurstelsel diterapkan oleh Gubernur Jenderal Graaf Johannes van den Bosch. Pada 13 Agustus 1830, van den Bosch memberi persetujuan penanaman tebu di keresidenan di Jawa Tengah dan Jawa Timur, termasuk Pekalongan yang menanam kopi dan nila (Surat Keterangan Cagar Budaya Pekalongan Nomor. 432/5860, 2017: 3).

\subsection{Kriteria dan Rekomendasi Penetapan}

\section{a. Kriteria Bangunan Cagar Budaya}

Kriteria suatu bangunan menjadi cagar budaya pada dasarnya merujuk pada Undang-Undang Nomor 11 Tahun 2010 tentang Cagar Budaya. Dalam regulasi disebutkan suatu bangunan dapat diusulkan menjadi bangunan cagar budaya apabila memenuhi beberapa kriteria yaitu berusia 50 (lima puluh) tahun atau lebih, mewakili masa gaya paling singkat berusia 50 (lima puluh) tahun, memiliki arti khusus bagi sejarah, ilmu pengetahuan, pendidikan, agama, dan/atau kebudayaan, dan memiliki nilai budaya bagi penguatan kepribadian bangsa (Undang-Undang Republik Indonesia Nomor 11 Tahun 2010)

Bangunan Cagar Budaya ini dapat berunsur tunggal atau banyak, dan/atau berdiri bebas atau menyatu dengan formasi alam. Pemerintah dan Pemerintah Daerah dapat melakukan pemeringkatan Cagar Budaya berdasarkan kepentingannya menjadi peringkat nasional, peringkat provinsi, dan peringkat kabupaten/kota berdasarkan rekomendasi Tim Ahli Cagar Budaya (TACB). Bangunan Cagar Budaya dapat ditetapkan menjadi Cagar Budaya peringkat nasional apabila memenuhi syarat wujud kesatuan dan persatuan bangsa, karya adiluhung yang mencerminkan kekhasan kebudayaan bangsa Indonesia, Cagar Budaya yang sangat langka jenisnya, unik rancangannya, dan sedikit jumlahnya di Indonesia, bukti evolusi peradaban bangsa serta pertukaran budaya lintas negara dan lintas daerah, baik yang telah punah maupun yang masih hidup di masyarakat; dan/atau contoh penting kawasan permukiman tradisional, 
lanskap budaya, dan/atau pemanfaatan ruang bersifat khas yang terancam punah (Undang-Undang Republik Indonesia Nomor 11 Tahun 2010).

Bangunan bersejarah dapat ditetapkan sebagai bangunan Cagar Budaya peringkat provinsi apabila mewakili kepentingan pelestarian Kawasan Cagar Budaya lintas kabupaten/kota, mewakili karya kreatif yang khas dalam wilayah provinsi, langka jenisnya, unik rancangannya, dan sedikit jumlahnya di provinsi, sebagai bukti evolusi peradaban bangsa dan pertukaran budaya lintas wilayah kabupaten/kota, baik yang telah punah maupun yang masih hidup di masyarakat, dan/atau berasosiasi dengan tradisi yang masih berlangsung. Pemeringkatan bangunan Cagar Budaya untuk tingkat provinsi dengan Keputusan Gubernur. Bangunan cagar budaya peringkat provinsi dapat dikoreksi peringkatnya berdasarkan rekomendasi Tim Ahli Cagar Budaya di setiap tingkatan. Bangunan Cagar Budaya dapat ditetapkan menjadi Cagar Budaya peringkat kabupaten/kota apabila sebagai bangunan Cagar Budaya yang diutamakan untuk dilestarikan dalam wilayah kabupaten/kota, mewakili masa gaya yang khas, tingkat keterancamannya tinggi, jenisnya sedikit; dan/atau, dan jumlahnya terbatas (Undang-Undang Republik Indonesia Nomor 11 Tahun 2010)

\section{b. Rekomendasi Bangunan Eks Rumah Dinas Residen sebagai Bangunan Cagar Budaya}

Berkaitan dengan penetapan eks rumah dinas residen sebagai bangunan cagar budaya peringkat provinsi apabila mewakili kepentingan pelestarian Kawasan Cagar, Budaya lintas kabupaten/kota, mewakili karya kreatif yang khas dalam wilayah provinsi, langka jenisnya, unik rancangannya, dan sedikit jumlahnya di provinsi, sebagai bukti evolusi peradaban bangsa dan pertukaran budaya lintas wilayah kabupaten/kota, baik yang telah punah maupun yang masih hidup di masyarakat, dan/atau berasosiasi dengan tradisi yang masih berlangsung (Undang-Undang No.11 Tahun 2010). Berdasarkan regulasi di atas, maka TACB Provinsi Jawa Tengah telah membuat rekomendasi penetapan terhadap eks Rumah Dinas Residen dengan merujuk pada pasal 5 UU Nomor 11 Tahun 2010. Syarat bangunan bersejarah dapat direkomendasi menjadi bangunan cagar budaya diantaranya bangunan tersebut berusia 50 (lima puluh) tahun atau lebih, mewakili masa gaya paling singkat berusia 50 (lima puluh) tahun, memiliki arti khusus bagi sejarah, ilmu pengetahuan, pendidikan, agama, dan/atau kebudayaan; dan, memiliki nilai budaya bagi penguatan kepribadian bangsa (Undang-Undang No.11 Tahun 2010).

\section{a) Eks Rumah Rumah Dinas Residen Banyumas}

Berdasarkan aturan di atas maka Eks rumah dinas residen Banyumas pada dasarnya layak direkomendasi untuk ditetapkan sebagai bangunan cagar budaya peringkat propinsi karena memenuhi kriteria dibangun pada tahun 1830, sehingga usianya sekitar 187 tahun. Gaya bangunan sudah mewakili paling singkat berusia 50 (lima puluh) tahun, dimana gaya bangunan empire style / neo klasik yang berkembang pada pertengahan abad ke-19. Pola bangunan juga hanya ditemukan pada bangunan kantor 
residen Banyumas di Kecamatan Banyumas. Bangunan ini memiliki arti khusus bagi sejarah, ilmu pengetahuan, pendidikan, agama, dan/atau kebudayaan (Surat Keterangan Cagar Budaya Banyumas Nomor. 432/5863: 2017: 10)

Bangunan ini menjadi simbol penggerak perubahan sosial bagi masyarakat Banyumas yang ditandai dengan adanya pengenalan sistem perkebunan yang telah memberikan pengetahuan baru bagi masyarakat untuk meningkatkan hasil pertanian terutama tanaman ekspor. Hadirnya Keresidenan Banyumas mempunyai nilai ekonomi bagi Hindia Belanda karena ditopang oleh daerah hinterland yang subur. Masyarakat Banyumas secara perlahan-lahan mulai lepas dari kehidupan adat dan mulai diperkenalkan menjadi buruh bebas. Masyarakat mulai mengenal sistem pendidikan barat yang diperlukan untuk mendukung pengelolaan perkebunan dengan pendirian sekolah-sekolah. Lulusan sekolah tersebut menjadi tenaga terampil dan administrasi di perkebunan. Sarana transportasi dibangun dan muncul embrio transportasi kereta api dan jalan raya yang mendukung pengangkutan hasil-hasil perkebunan.

Eks rumah dinas residen mempunyai arti penting bagi sejarah pemerintahan daerah. Kehadiran keresidenan memiliki kontribusi budaya bagi penguatan kepribadian bangsa, diantaranya sebagai penghargaan terhadap kondisi lingkungan lokal yang dilakukan oleh ahli bangunan Belanda, pengenalan sistem pendidikan barat yang rasional telah memperkaya kebudayaan Indonesia, menjadi penciri modernisasi dalam sistem birokrasi pemerintahan daerah yang modern yang berdampak pada perekrutan pegawai-pegawai pemerintah yang berpendidikan barat sehingga masyarakat Banyumas memanfaatkan kesempatan untuk kemajuan, masyarakat pada masa tanam paksa mulai mengenal sistem ekonomi modern sebagai prasyarat menuju masyarakat yang modern, dan adanya sistem liberal mendorong kreativitas ekonomi masyarakat dengan lahirnya diversifikasi ekonomi yang menunjukkan kemampuan penduduk dalam beradaptasi dengan lingkungannya (Surat Keterangan Cagar Budaya Banyumas Nomor. 432/5863: 2017: 10-11)

\section{b) Eks Rumah Dinas Residen Kedu}

Eks Rumah Dinas Residen Kedu dibangun pada tahun 1813, sehingga usianya sekitar 209 tahun. Gaya bangunan tersebut termasuk bangunan langka karena bergaya arsitektur empire style yang telah dikembangkan ke arsitektur Indis yang berkembang pada pertengahan abad ke-19. Meskipun pada saat itu belum diberlakukan Cultuur Stelsel (tanam paksa), masyarakat sudah mulai mengenal tanaman perkebunan untuk ekspor. Keberadaan keresidenan ini menunjukkan bahwa Keresidenan Kedu di Magelang mempunyai nilai ekonomi bagi Hindia Belanda karena daerah ini ditopang hinterland yang subur (Surat Keterangan Cagar Budaya Kedu Nomor. 432/5861, 2017: 9).

Pada masa sebelum tanam paksa, masa tanam paksa, dan masa liberal, pemerintah keresidenan secara perlahan-lahan mulai memperkenalkan kerja bebas, sehingga masyarakat mempunyai pilihan alternatif dalam menjalankan pekerjaan. Pada masa liberal, masyarakat mempunyai kesempatan bekerja 
di perkebunan secara bebas. Sarana transportasi jalan raya mulai berkembang, meskipun Magelang tidak dilalui pembangunan jalan Deandels. Melalui perbaikan transportasi ini, dapat mendukung pengangkutan hasil-hasil perkebunan seperti Nila /Tarum dan tembakau untuk wilayah di sekitar Kedu. Arti penting bagi sejarah terutama memberikan sumbangan data-data untuk ilmu sejarah, arkeologi, dan arsitektur (Surat Keterangan Cagar Budaya Kedu Nomor. 432/5861, 2017: 10-11).

\section{c) Eks Rumah Dinas Residen Pati}

Eks Rumah Dinas Residen Pati dibangun pada tahun 1810, sehingga usianya sekitar 208 tahun. Gaya bangunan tersebut termasuk bangunan langka karena bergaya arsitektur empire style yang dipadu dengan dengan fungsi-fungsi bangunan tropis. Munculnya gaya terjadi sejak awal abad ke-19. Bangunan ini mewakili pemerintah Hindia Belanda di wilayah keresidenan Pati dan menjadi simbol penggerak perubahan pemerintahan dan sosial bagi masyarakat Pati yaitu perpindahan rumah dinas residen Keresidenan Jepara dari Jepara ke Pati menandakan bangkitnya Pati di sektor ekonomi karena dilalui oleh pembangunan jalan Deandels. Keberadaan eks rumah dinas residen Jepara di Pati ini menunjukkan bahwa Pati dipandang mempunyai nilai ekonomi bagi Deandels, Raffles, dan pemerintahan Hindia Belanda karena letaknya yang strategis di pantai utara Jawa. Pada masa Deandels dan Raffles, masyarakat mulai dikenalkan ekonomi uang dan kerja bebas (Surat Keterangan Cagar Budaya Pati Nomor 432/5865: 2017: 9).

\section{d) Eks Rumah Dinas Residen Pekalongan}

Eks Rumah Dinas Residen Pekalongan dibangun pada tahun 1850, jadi usianya sekitar 167 tahun. Bangunan ini mewakili pemerintah Hindia Belanda di wilayah keresidenan Pekalongan dan sebagai simbol perubahan masyarakat di sektor ekonomi dan pemerintahan. Masa dibangunnya eks rumah dinas residen ini merupakan periode mulai menurunnya sistem ekonomi cultuur stelsel sebagai kebijakan pemerintah Hindia Belanda di Jawa, khususnya di Pekalongan. Keberadaan bangunan Kantor dinas residen Pekalongan berpengaruh secara tidak langsung terhadap munculnya pola masyarakat untuk menjadi pekerja bebas di perkebunan. Keberadaan Kantor dinas residen di Pekalongan berdampak pada kebijakan perbaikan sarana transportasi di Pekalongan sebagai jalur pantura (Surat Keterangan Cagar Budaya Pekalongan Nomor 432/5862: 2017: 7-8)

\section{Simpulan}

Jawa Tengah kaya akan bangunan bersejarah berupa eks rumah dinas residen yang yang terdapat di beberapa daerah. Bangunan eks rumah dinas residen layak ditetapkan menjadi bangunan cagar budaya peringkat provinsi. Bangunan Cagar Budaya eks rumah dinas residen merupakan bangunan yang berusia 50 (lima puluh) tahun atau lebih, mewakili masa Gaya paling singkat berusia 50 (lima puluh) tahun, memiliki nilai budaya bagi penguatan kepribadian bangsa, mempunyai arti penting bagi sejarah, ilmu 
pengetahuan, pendidikan, agama, dan/atau kebudayaan. Bangunan cagar budaya ini merupakan peninggalan Pemerintah Kolonial Hindia Belanda sebagai pusat administrasi pemerintahan. Oleh karena itu, bangunan cagar budaya ini perlu dilestarikan. Pelestarian ini sebagai upaya dinamis untuk mempertahankan keberadaan Cagar Budaya dan nilainya dengan cara melindungi, mengembangkan, dan memanfaatkannya untuk kesejahteraan masyarakat.

\section{Daftar Pustaka}

Algemeen Verslag Residentie Japara en Joana 1830

Arafah, Burhanudin. Tanpa Tahun. Warisan Budaya, Pelestarian dan Pemanfaatannya. Fakultas Ilmu Budaya, Universitas Hasanudin. Dalam http://www.yayasankertagama. org/article/article4.pdf

Day, Clive. 1904. The Policy and Administration of The Dutch in Java. New York: The Macmillan Company.

der Aa, A.J. Van. 1857. Nederlands Oost-Indie, vierde deel. Breda: Broese en Comp.

der Lith, P.A. van. 1896. Encyclopaedie van Nederlandsch Indië, tweede deel. 's Gravenhage: Martinus Nijhof

Garraghan, Gilbert J. 1947. A Guide to Historical Method. New York: Fordham University Press.

Gottschalk, Louis. 1975. Mengerti Sejarah. Terjemahan Nugroho Notosusanto. Jakarta:Yayasan Penerbit Universitas Indonesia

Herlina, Nina. 2008. Metode Sejarah. Bandung: Satya Historika.

Keputusan Dirjen Kebudayaan nomor 100/ E.E 2/ KP/ 2018 Tentang Pedoman Tata Kerja Tim Ahli Cagar Budaya Nasional Dirjen Kebudayaan

Lembaran Negara 1945

Margana, Sri dan M Nursam. 2010. Kota-Kota di Jawa, Identitas Gaya Hidup dan Permasalahannya. Yogyakarta: Ombak.

Peraturan Daerah Provinsi Jawa Tengah Nomor 10 Tahun 2013 Tentang Pelestarian Dan Pengelolaan Cagar Budaya Provinsi Jawa Tengah

Setiyanto, A. 2015. Orang-Orang Besar Bengkulu: Riwayatmu Dulu.Yogyakarta: Ombak.

Staadsblad 1933 No. 251

Saebani, Beni Ahmad. tt. Metode Penelitian, Bandung: Pustaka Setia

Suroyo, A.M. Djuliati dkk, 2003. Penelusuran Hari Jadi Jawa Tengah (Semarang: Kerja Sama Pemerintah Provinsi Jawa Tengah dengan Jurusan Sejarah Fakultas Sastra Universitas Diponegoro).

Suryo, Djoko, 1989. Sejarah Sosial Pedesaan Karesidenan Semarang 1830-1900. Yogyakarta: Pusat Antar Universitas Studi Sosial UGM.

Sutherland, Heather, 1988, Terbentuknya Sebuah Elite Birokrasi. Terjemahan. Jakarta: Sinar Harapan.

Sutherland, Heather, 1979. "The Making of Bureaucratic Elite. Singapore, Kuala Lumpur. Hongkong: Heinemann Educational Book (Asia) Ltd.

Tim Ahli Cagar Budaya Provinsi Jawa Tengah, 2017. Surat Keterangan Cagar Budaya Pekalongan Nomor. 432/5860

Tim Ahli Cagar Budaya Provinsi Jawa Tengah, 2017. Surat Keterangan Cagar Budaya Kedu Nomor. $432 / 5861$

Tim Ahli Cagar Budaya Provinsi Jawa Tengah, 2017. Surat Keterangan Cagar Budaya Banyumas Nomor. 432/5863

Tim Ahli Cagar Budaya Provinsi Jawa Tengah, 2017. Surat Keterangan Cagar Budaya Pati Nomor. $432 / 5865$

Undang-Undang No.11 Tahun 2010 Tentang Cagar Budaya

Veth. P.J. 1882. Jawa: Geographisch, Ethnologisch, Historisch, derde deel.Haarlem: Erven F. Bohn;

Wijaya, Daya Negri. 2017. “Thomas Stamford Raffles Di Bengkulu: Politisi Atau Ilmuwan?", dalam Paramita: Historical Studies Journal, 27 (1), 2017. pp. 59. 